\title{
Physico-Chemical and Bacteriological Characterization of Spring and Well Water in Bamenda III (NW Region, Cameroon)
}

\author{
Alice Magha ${ }^{1,2, ~ *, ~ M a r g a r e t ~ T i t a ~ A w a h ~}{ }^{1}$, Gus Djibril Kouankap Nono ${ }^{1}$, Pierre Wotchoko ${ }^{1}$, \\ Mispa Ayuk Tabot ${ }^{1}$, Veronique Kamgang Kabeyene ${ }^{2}$ \\ ${ }^{1}$ Department of Geology, HTTC, The University of Bamenda, Bambili; Bamenda, Cameroon \\ ${ }^{2}$ Department of Earth Sciences, Faculty of Sciences, University of Yaoundé 1, Yaoundé, Cameroon
}

\section{Email address:}

amufur@yahoo.com (A. Magha),mtitawa2000@yahoo.com (M. T. Awah), kouankap@yahoo.fr (G. D. K. Nono), pierrewotchoko@yahoo.fr (P. Wotchoko), ayuktabot24@yahoo.com (M. A. Tabot), gemskruy@yahoo.fr (V. K. Kabeyene)

\section{To cite this article:}

Alice Magha, Margaret Tita Awah, Gus Djibril Kouankap Nono, Pierre Wotchoko, Mispa Ayuk Tabot, Veronique Kamgang Kabeyene. Physico-Chemical and Bacteriological Characterization of Spring and Well Water in Bamenda III (NW Region, Cameroon). American Journal of Environmental Protection. Vol. 4, No. 3, 2015, pp. 163-173. doi: 10.11648/j.ajep.20150403.17

\begin{abstract}
Bamenda is a major town in the NW Region of Cameroon and constitutes part of the Cameroon Volcanic line. In the frame of this work, four springs and three wells in the Bamenda III council area were investigated to evaluate the physicochemical and bacteriological characteristics of their waters. All the water points yielded $\mathrm{pH}$ values below 6.5 and were classified as acidic water. Electrical conductivity ranged between $0.04-2.38 \mu \mathrm{m} / \mathrm{cm}$. The relative abundance of major ions (meq/l) was $\mathrm{Ca}^{2+}>\mathrm{Mg}^{2+}>\mathrm{K}^{+}>\mathrm{Na}^{+}$for cations and $\mathrm{HCO}_{3}{ }^{-}>\mathrm{SO}_{4}{ }^{2-}>\mathrm{NO}_{3}{ }^{-}>\mathrm{PO}_{4}{ }^{3-}$ for anions. Major ion concentrations were within the WHO guidelines for drinking water, but $\mathrm{Ca}^{2+}(110-1770 \mathrm{mg} / \mathrm{l})$ and $\mathrm{Mg}^{2+}(97.05-236.85 \mathrm{mg} / \mathrm{l})$ concentrations were much higher and above WHO limits. Main water types in the dry season were Ca-Mg-HCO3 while in rainy season the main water types were $\mathrm{Ca}-\mathrm{Mg}-\mathrm{HCO} 3$ and a mixed $\mathrm{Ca}-\mathrm{Mg}$-SO4. Bacterial analysis revealed that the water samples were highly polluted and classified B, C and D according to Cheesbrough classification. The spring and well waters analysed are not suitable for drinking and domestic purposes therefore the population of Bamenda III which depends on the mentioned water for drinking and domestic purposes may face serious health problems if appropriate actions are not taken to prevent and mitigate the problems.
\end{abstract}

Keywords: Bamenda III, Faecal Bacterial Analysis, Physico-Chemical Analysis, Water Quality

\section{Introduction}

Cameroon is endowed with numerous water sources [1,2]. It is a country with the second highest volume of available water in Africa [3]. Groundwater constitutes 21.5\% (57 billion $\mathrm{m} 3$ ) of this resource and plays a very important role in the socio-economic life of the country.

The setting and evolution of most forms and pattern of settlements is linked to the availability of reliable and substantial water sources, and the fertility of volcanic soils have brought through ancient times the intense settlement and agricultural exploitation of the lower flanks of volcanoes [4]. This is the case of Bamenda town, a rapidly growing town which belongs to the Cameroon Volcanic Line (CVL) the principal watershed of the country [5]. Many thermal and mineral springs typified by the $\mathrm{Fe}-\mathrm{Mg}-\mathrm{Ca}-\mathrm{HCO}_{3}{ }^{-}$or $\mathrm{Na}-$ $\mathrm{HCO}_{3}^{-}$compositions are found along the CVL [6]. The chemical composition of surface and groundwater is controlled by many factors that include composition of precipitation, mineralogy of watershed and aquifers, climate and topography as well as anthropogenic influence such as urban, industrial and agricultural activites. These factors combine to create diverse water types that change spacially and temporally [3]. When water perculates through formations, it comes in contact with geologic formations and ions are exchanged especially during the process of weathering and alteration. These rocks release minerals whose ions enter aquifers and alter the chemical composition.

Geochemical studies from groundwater and surface water can provide a better understanding of potential water quality variations due to geology and land use practices [7-9]. 
Knowledge of the levels of microorganisms in water is also important for indexing the health harzard associated with its use, adopting meaningful interventions and improving bacterial water quality [10]. The Bamenda III Council Area is made up of many springs and wells on which about $80 \%$ of the population depends for both drinking and domestic purposes. Characterizing the mentioned water is of great importance to determine if the population is at risk. In this paper we present the evaluation of the physico-chemical and bacteriological qualities of some springs and wells in Bamenda III.

\section{Natural Setting of the Study Area}

Bamenda III is found in Mezam Division in the North West Region of Cameroon between latitudes $06^{\circ} 00^{\prime} \mathrm{N}$ and $06^{\circ} 89^{\prime} \mathrm{N}$ and longitudes $10^{\circ} 13^{\prime} \mathrm{E}$ and $10^{\circ} 28^{\prime} \mathrm{E}$ (Figure 1). This town is located at the central part of the Cameroon Volcanic Line, and is implanted below the high lava plateau, at an altitude of about $1500 \mathrm{~m}$. Bamenda III Subdivision is made up of two villages: Nkwen and Ndzah with about 250,000 inhabitants and a surface area of $74.61 \mathrm{~km} 2$.

The climate is mainly of the equatorial type with two main seasons, the rainy season (April to October) and the dry season (November to March). Absolute annual average precipitation ranges from $1700 \mathrm{~mm}$ to $2824 \mathrm{~mm}$ and exhibits fluctuations [11].

The study area forms part of the Bamenda Mountains which lie along the Cameroon Volcanic Line. It is made up of a basement rock which is mainly composed of leucogranites of Precambrian age [12]. The basement rock is overlain by volcanic materials composed of mafic and felsic lavas. The mafic lavas include basalts which outcrop as lava flows and pyroclastic deposits respectively, while the felsic lavas include trachytes and rhyolites [13].

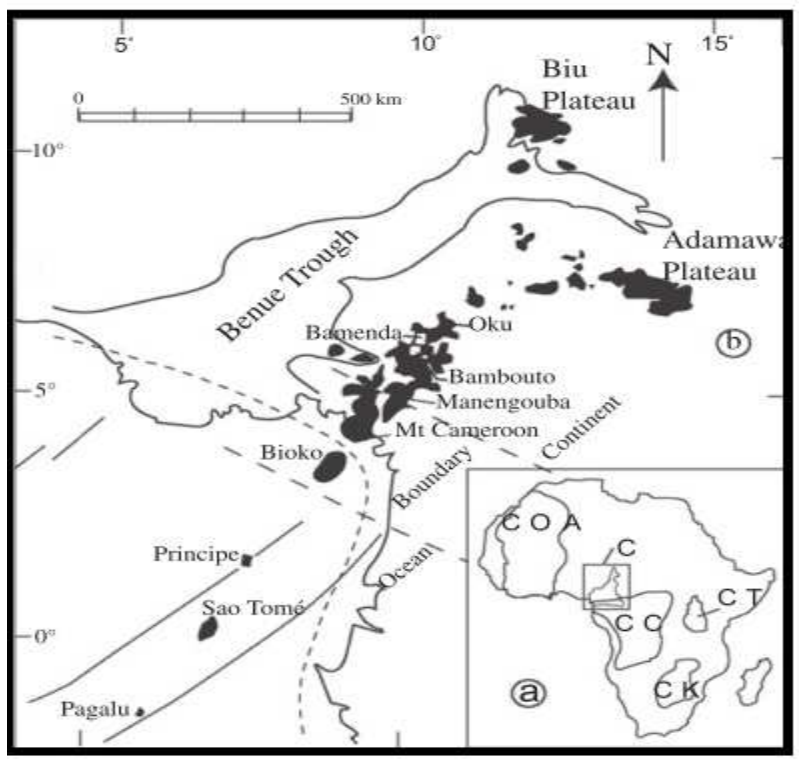

Figure 1. Location of Bamenda along the Cameroon Volcanic Line. From [14].

\section{Methods}

\subsection{Field Work}

Field studies were carried out in two phases and at different seasons of the year; the first phase took place in the rainy season (September) and the second phase in the dry season (February). Water samples were collected from 4 springs and 3 wells and at each sampling point, two sets of samples were collected and in one of the sets of samples $5 \mathrm{ml}$ of $\mathrm{HCl}$ were added to stabilise the heavy metal concentration. Sampling points were chosen in relation to their uses by the population.

\subsection{Laboratory Analysis}

Physico-chemical and bacteriological analyses were performed in the laboratory of the Faculty of Agronomy and Agricultural Sciences (FASA) in the University of Dschang, Cameroon.

\subsection{Physical Analysis}

For physical analysis, Total Dissolved Solids was determined. An NTU Turbidimeter (DRT 100B HF model type) was used to measure turbidity. Electrical Conductivity was determined using a Conductivity meter (WTW LF 521 model type).

\subsection{Major Cations}

Sodium $\left(\mathrm{Na}^{+}\right)$and potassium $\left(\mathrm{K}^{+}\right)$were determined by flame photometry. The analysis of Calcium $\left(\mathrm{Ca}^{2+}\right.$ was done by titration with $0.02 \mathrm{M}$ solution of $\mathrm{Ca}$ - EDTA together with $1 \mathrm{ml}$ of TEA and $1 \mathrm{ml}$ of $5 \% \mathrm{KCN}$. The determination of magnesium $\left(\mathrm{Mg}^{2+}\right)$ was done in a similar manner; ammonium $\left(\mathrm{NH}_{4}{ }^{+}\right)$was analysed using the colorimetric method.

\subsection{Major Anions}

Chloride $\left(\mathrm{Cl}^{-}\right)$was analysed by titration. Nitrates $\left(\mathrm{NO}_{3}^{-}\right)$ and phosphate $\left(\mathrm{PO}_{4}{ }^{3}\right)$ were determined using colorimetry. Sulphates $\left(\mathrm{SO}_{4}{ }^{2}\right)$ were determined by turbidimetry and Bicarbonates $\left(\mathrm{HCO}_{3}^{-}\right)$concentrations by titration.

\subsection{Bacteriological Analysis}

This was done on three sets of samples (two springs and one well) to determine the presence of faecal streptococcus, Escherichia coli, faecal and total coliform using the membrane filter procedure. $1 \mathrm{ml}$ of water sample was added to $9 \mathrm{ml}$ of distilled water. Each sample was diluted three times. A membrane was placed on a sterilized Wheaton Filtration funnel used to filter $20 \mathrm{ml}$ of undiluted sample. The funnel was sterilized after each filtration to avoid interferences. Several diluted samples were then processed so as to get filter plates with appropriate range of colonies. These filter plates were placed in an incubator at different temperature conditions for different bacteria. These were: $44 \mathrm{oC}$ for E-coli and feacal coliform, $350 \mathrm{C}$ for streptococcus and total coliform. 


\section{Results}

The physico-chemical characteristics of the studied water were similar, whether it was from well or from spring but significant differences were noted with the different seasons.

\subsection{Physical Characteristics}

Water temperatures were higher during the dry season and lower in the rainy season for all sampling points with the average of $22.6^{\circ} \mathrm{C}$ in the rainy season and of $26.31^{\circ} \mathrm{C}$ in the dry season (Figure 2). The average $\mathrm{pH}$ value was higher in the rainy season (5.71) than in the dry season (5.47) as shown in Figure 2, but all water points yielded acidic to barely acidic water (Table 1 ).

The values for EC were very low regardless of the sampling point and season but in the dry season a highest value $(2.38 \mu \mathrm{S} / \mathrm{cm})$ was recorded in AMW3.

Turbidity was higher in the rainy season than in the dry season with the respective average value recorded of 8.14 and 2.40 (Table 1).

Table 1. Variation of Temperature, PH, Electrical Conductivity, and Turbidity in the rainy season and dry season.

\begin{tabular}{lllllllll}
\hline & \multicolumn{2}{l}{ Temperature $\left(\mathbf{T}^{\circ}\right)$} & $\mathbf{p H}$ & & \multicolumn{2}{l}{ Electrical conductivity (EC) } & Turbidity \\
\hline $\begin{array}{l}\text { Sampling } \\
\text { points }\end{array}$ & $\begin{array}{l}\text { Rainy } \\
\text { Season }\end{array}$ & Dry Season & Rainy Season & Dry Season & Rainy Season & Dry Season & Rainy Season & Dry Season \\
\hline $\mathrm{AMS}_{1}$ & 24.7 & 27.7 & 5.4 & 6.5 & 0.03 & 0.05 & 7.3 & 2.8 \\
$\mathrm{AMS}_{2}$ & 21.6 & 26.4 & 5.8 & 6 & 0.04 & 0.04 & 5.6 & 2.2 \\
$\mathrm{AMS}_{3}$ & 21.2 & 24 & 6.0 & 5.4 & 0.03 & 0.05 & 9.6 & 2 \\
$\mathrm{AMS}_{4}$ & 22.4 & 26.2 & 5.2 & 6.3 & 0.20 & 0.03 & 7.6 & 4.4 \\
$\mathrm{AMW}_{1}$ & 24 & 27.9 & 6.7 & 6.2 & 0.29 & 0.11 & 13.5 & 1.9 \\
$\mathrm{AMW}_{2}$ & 22.3 & 27 & 5.3 & 5.4 & 0.16 & 0.13 & 6.9 & 1.8 \\
AMW & 22 & 25 & 5.6 & 2.5 & 0.05 & 4.7 & 6.5 & 1.7 \\
Average & 22,60 & 26,31 & 5.71 & 5.47 & 0.11 & 0.73 & 8.14 & 2.40 \\
\hline
\end{tabular}
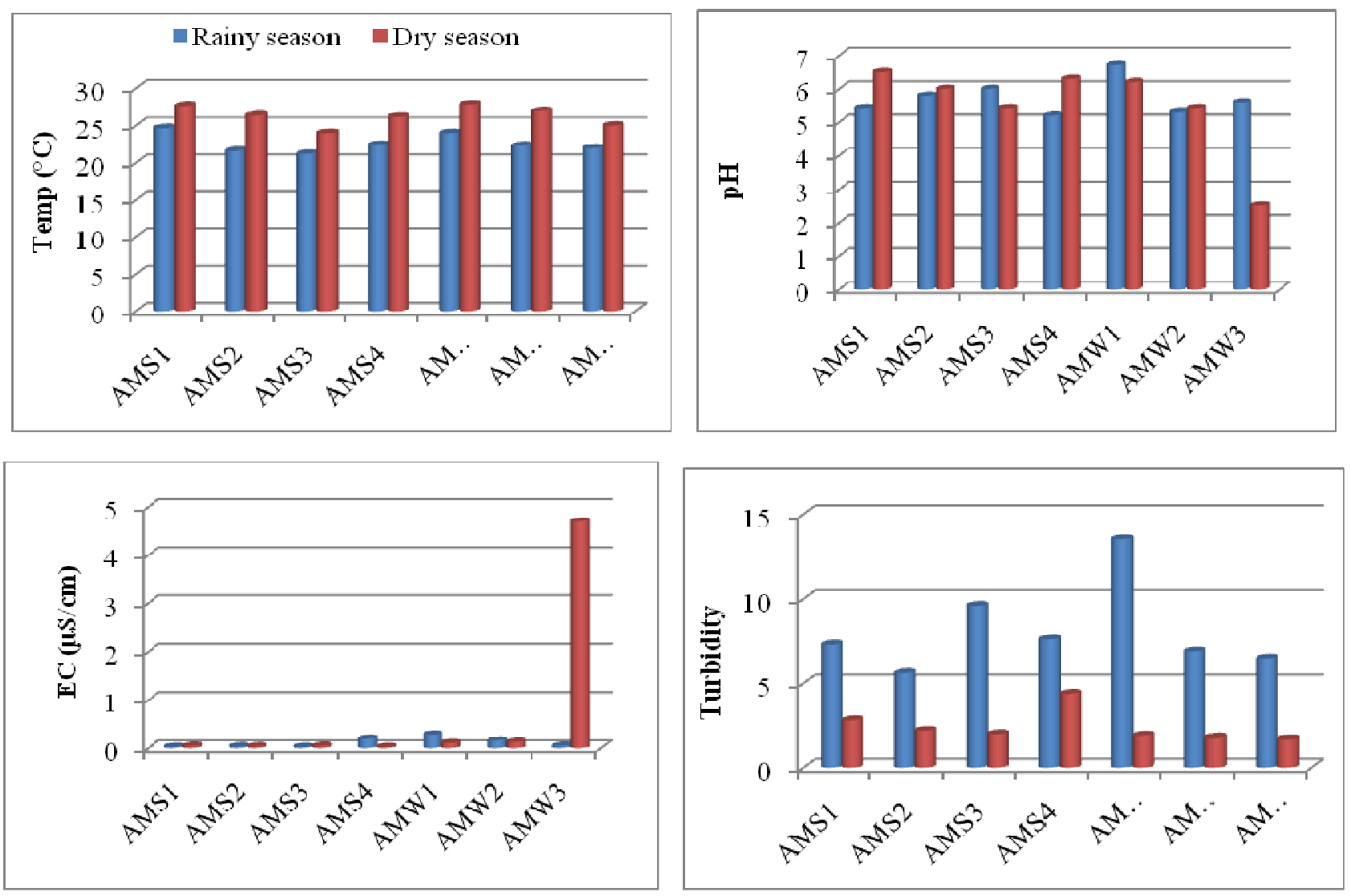

Figure 2. Seasonal variation of physical parameters (Temperature, pH, Electrical conductivity, Turbidity).

\subsection{Chemical Characteristics of Cations}

$\mathrm{K}^{+}$and $\mathrm{Na}^{+}$concentrations were high in the dry season and just barely detectable in the rainy season. There were no differences for the different sampling points, their respective average values for the rainy season were $0.39 \mathrm{mg} / \mathrm{l}$ and 
$0.30 \mathrm{mg} / 1$, these values for dry season were $24.72 \mathrm{mg} / 1$ and $11.37 \mathrm{mg} / 1$.

Regarding the average concentration in the dry season, $\mathrm{Ca}^{2+}$ was the most abundant cation in all the water samples with an average value above $500 \mathrm{mg} / \mathrm{l}$ (Table 2). $\mathrm{Ca}^{2+}$ was also higher in the dry season than in the rainy season for all samples.

$\mathrm{Mg}^{2+}$ was the second abundant cation present in the analysed water with an average of $232.3 \mathrm{mg} / \mathrm{l}$ in the rainy season and $126.57 \mathrm{mg} / \mathrm{l}$ in the dry season.
The $\mathrm{NH}_{4}^{+}$values were higher in the rainy season and barely detectable in the dry season (Figure 3) with average values ranging from $12.06 \mathrm{mg} / \mathrm{l}$ in the rainy season to $0.0073 \mathrm{mg} / \mathrm{l}$ in the dry season.

$\mathrm{Fe}^{2+}$ was the least abundant cation in the water samples with the highest concentration of $1.14 \mathrm{mg} / \mathrm{l}$ in $\mathrm{AMW}_{2}$ during the dry season. In the rainy season $\mathrm{Fe}^{2+}$ was not detected in $\mathrm{AMS}_{3}, \mathrm{AMS}_{4}, \mathrm{AMW}_{1}, \mathrm{AMW}$ and $\mathrm{AMW}_{3}$ while in the dry season it was not detected in $\mathrm{AMS}_{1}$ and $\mathrm{AMS}_{2}$ (Table 2).

Table 2. Variation of Cations in the rainy season and dry season.

\begin{tabular}{|c|c|c|c|c|c|c|c|c|c|c|c|c|}
\hline & $\mathbf{K}+$ & & $\mathrm{Na}+$ & & $\mathrm{Ca} 2+$ & & Mg2+ & & NH4+ & & $\mathrm{Fe} 2+$ & \\
\hline $\begin{array}{l}\text { Sampling } \\
\text { points }\end{array}$ & $\begin{array}{l}\text { Rainy } \\
\text { Season }\end{array}$ & $\begin{array}{l}\text { Dry } \\
\text { Season }\end{array}$ & $\begin{array}{l}\text { Rainy } \\
\text { Season }\end{array}$ & $\begin{array}{l}\text { Dry } \\
\text { Season }\end{array}$ & $\begin{array}{l}\text { Rainy } \\
\text { Season }\end{array}$ & $\begin{array}{l}\text { Dry } \\
\text { Season }\end{array}$ & $\begin{array}{l}\text { Rainy } \\
\text { Season }\end{array}$ & $\begin{array}{l}\text { Dry } \\
\text { Season }\end{array}$ & $\begin{array}{l}\text { Rainy } \\
\text { Season }\end{array}$ & $\begin{array}{l}\text { Dry } \\
\text { Season }\end{array}$ & $\begin{array}{l}\text { Rainy } \\
\text { Season }\end{array}$ & $\begin{array}{l}\text { Dry } \\
\text { Season }\end{array}$ \\
\hline $\mathrm{AMS}_{1}$ & 0.39 & 23.64 & 0.11 & 7.94 & 240 & 320 & 194.4 & 194 & 8.40 & 0.0062 & 0.89 & - \\
\hline $\mathrm{AMS}_{2}$ & 0.40 & 25.39 & 0.37 & 8.01 & 280 & 400 & 109.4 & 219 & 12.88 & 0.0048 & 0.83 & - \\
\hline $\mathrm{AMS}_{3}$ & 0.39 & 25.55 & 0.37 & 12.38 & 60 & 160 & 145.8 & 255 & 14 & 0.0070 & - & 0.39 \\
\hline $\mathrm{AMW}_{1}$ & 0.39 & 24.89 & 0.37 & 5.54 & 256 & 980 & 328.1 & 12 & 10.36 & 0.0084 & - & 0.05 \\
\hline $\mathrm{AMW}_{2}$ & 0.39 & 24.72 & 0.37 & 26.67 & 340 & 800 & 461.7 & 12 & 12.77 & 0.0076 & - & 1.14 \\
\hline $\mathrm{AMW}_{3}$ & 0.39 & 24.18 & 0.11 & 10.64 & 180 & 660 & 180 & 24 & 9.24 & 0.0087 & - & 0.18 \\
\hline Average & 0.39 & 24.72 & 0.30 & 11.37 & 230.9 & 545.7 & 232.3 & 126.57 & 12.06 & 0.0073 & 0.25 & 0.26 \\
\hline
\end{tabular}
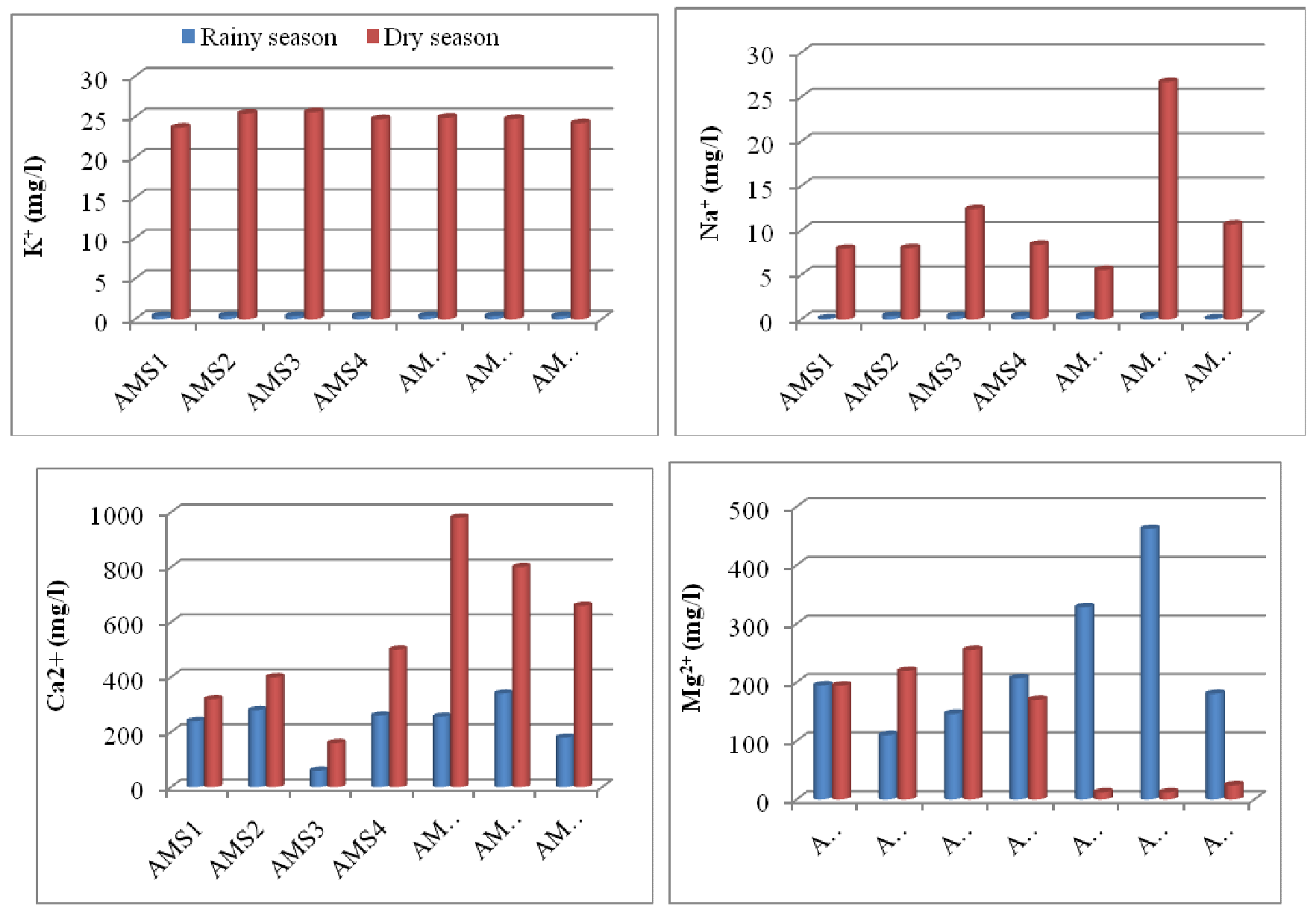

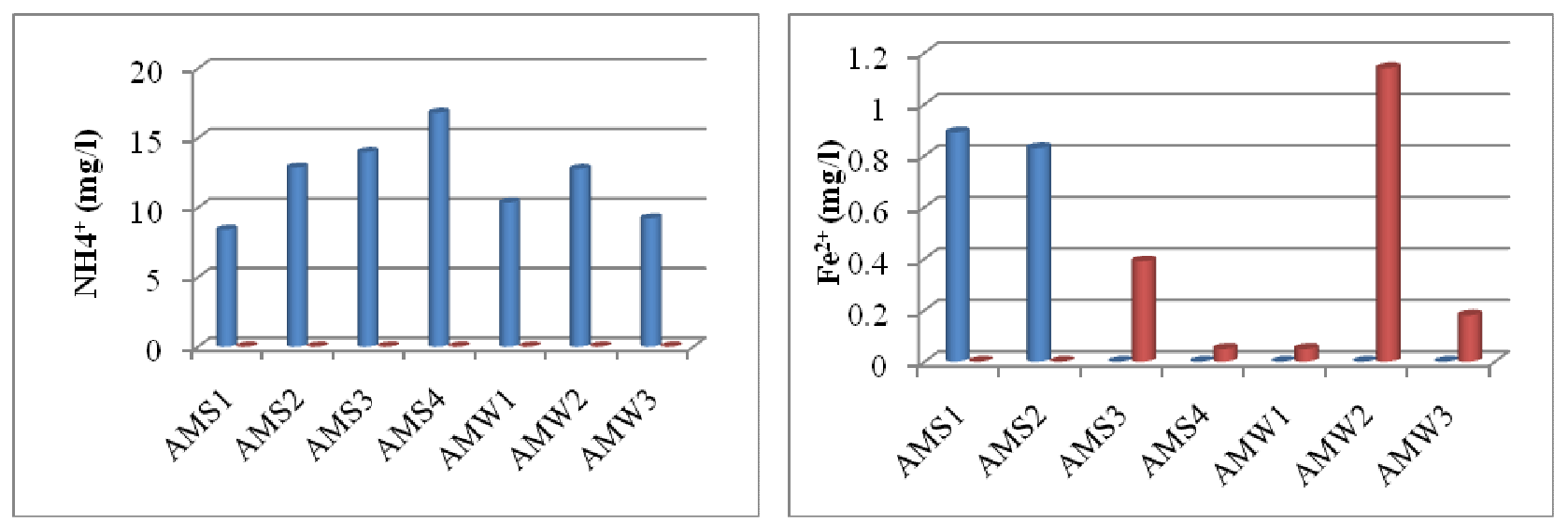

Figure 3. Seasonal variation of cations $\left(\mathrm{K}^{+}, \mathrm{Na}^{+}, \mathrm{Ca}^{2+}, \mathrm{Mg}^{2+}, \mathrm{NH}_{4}^{+}, \mathrm{Fe}^{2+}\right)$.

\subsubsection{Anions}

$\mathrm{Cl}^{-}$was completely absent in all the samples in the dry season. In the rainy season, high $\mathrm{Cl}^{-}$values were recorded only in $\mathrm{AMS}_{4}(158 \mathrm{mg} / \mathrm{l})$ and $\mathrm{AMW}_{2}(270 \mathrm{mg} / \mathrm{l})$ as shown in Table 3.

Average values for $\mathrm{HCO}_{3}{ }^{-}$were higher in the rainy season $(65.36 \mathrm{mg} / \mathrm{l})$ than in the dry season $(50.13 \mathrm{mg} / \mathrm{l})$.

The values of $\mathrm{PO}_{4}{ }^{3-}$ were higher in the dry season than in the rainy season but all the values were less than $2 \mathrm{mg} / 1$ with an average of $0.16 \mathrm{mg} / \mathrm{l}$ in the dry season and of $1.11 \mathrm{mg} / 1$ in the rainy season (Table 3 ). $\mathrm{NO}_{3}{ }^{-}$and $\mathrm{SO}_{4}{ }^{2-}$ were barely detectable in the dry season with the respective average values of $0.0033 \mathrm{mg} / 1$ and $0.05 \mathrm{mg} / \mathrm{l}$. In the rainy season for each cation there were just minor differences in the sampling points, $\mathrm{NO}_{3}{ }^{-}$concentration yielded an average of $7.68 \mathrm{mg} / 1$ and $\mathrm{SO}_{4}{ }^{2-}$ an average of $17.61 \mathrm{mg} / \mathrm{l}$ in the rainy season as presented in table 3 and Figure 4.

Table 3. Variation of Anions in the rainy season and dry season.

\begin{tabular}{|c|c|c|c|c|c|c|c|c|c|c|}
\hline & $\mathrm{Cl}^{-}$ & & $\mathrm{HCO}_{3}^{-}$ & & $\mathrm{PO}_{4}{ }^{{ }^{-}}$ & & $\mathrm{NO}_{3}^{-}$ & & $\mathrm{SO}_{4}{ }^{2-}$ & \\
\hline $\begin{array}{l}\text { Sampling } \\
\text { points }\end{array}$ & $\begin{array}{l}\text { Rainy } \\
\text { Season } \\
\end{array}$ & $\begin{array}{l}\text { Dry } \\
\text { Season } \\
\end{array}$ & $\begin{array}{l}\text { Rainy } \\
\text { Season } \\
\end{array}$ & Dry Season & $\begin{array}{l}\text { Rainy } \\
\text { Season } \\
\end{array}$ & $\begin{array}{l}\text { Dry } \\
\text { Season } \\
\end{array}$ & $\begin{array}{l}\text { Rainy } \\
\text { Season } \\
\end{array}$ & $\begin{array}{l}\text { Dry } \\
\text { Season } \\
\end{array}$ & $\begin{array}{l}\text { Rainy } \\
\text { Season } \\
\end{array}$ & $\begin{array}{l}\text { Dry } \\
\text { Season } \\
\end{array}$ \\
\hline $\mathrm{AMS}_{1}$ & - & - & 57.95 & 75.6 & 0.25 & 1.67 & 11.20 & 0.0028 & 15 & 0.05 \\
\hline $\mathrm{AMS}_{2}$ & - & - & 30.50 & 40.32 & 0.19 & 1.23 & 8.40 & 0.0006 & 12 & 0.05 \\
\hline $\mathrm{AMS}_{3}$ & - & - & 39.65 & 42.84 & 0.19 & 1.23 & 5.60 & 0.0022 & 18 & 0.06 \\
\hline $\mathrm{AMS}_{4}$ & 158 & - & 33.55 & 37.8 & 0.13 & 0.80 & 7.28 & 0.0034 & 12 & 0.05 \\
\hline $\mathrm{AMW}_{1}$ & - & - & 231.80 & 116.55 & 0.13 & 1.23 & 5.88 & 0.0048 & 26 & 0.06 \\
\hline $\mathrm{AMW}_{2}$ & 270 & - & 30.50 & 37.8 & 0.13 & 0.80 & 7.00 & 0.0045 & 23 & 0.05 \\
\hline $\mathrm{AMW}_{3}$ & - & - & 33.55 & - & 0.13 & 0.80 & 8.40 & 0.0048 & 17.3 & 0.05 \\
\hline Average & 61.14 & 0.00 & 65.36 & 50.13 & 0.16 & 1.11 & 7.68 & 0.0033 & 17.61 & 0.05 \\
\hline
\end{tabular}
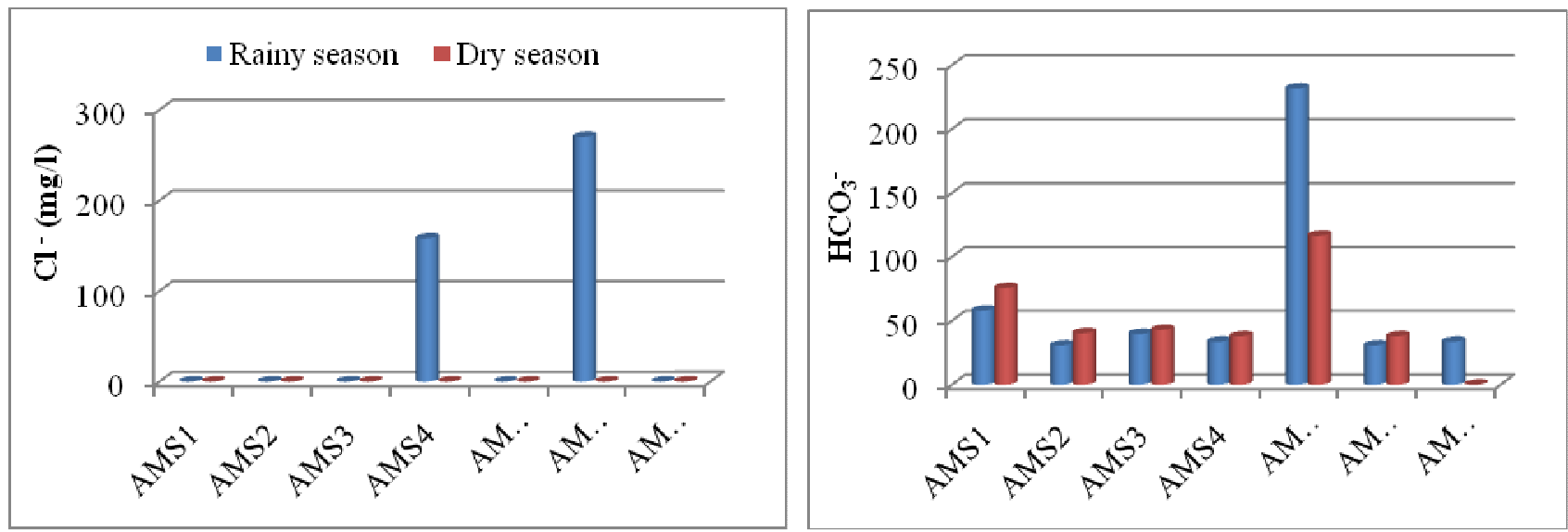

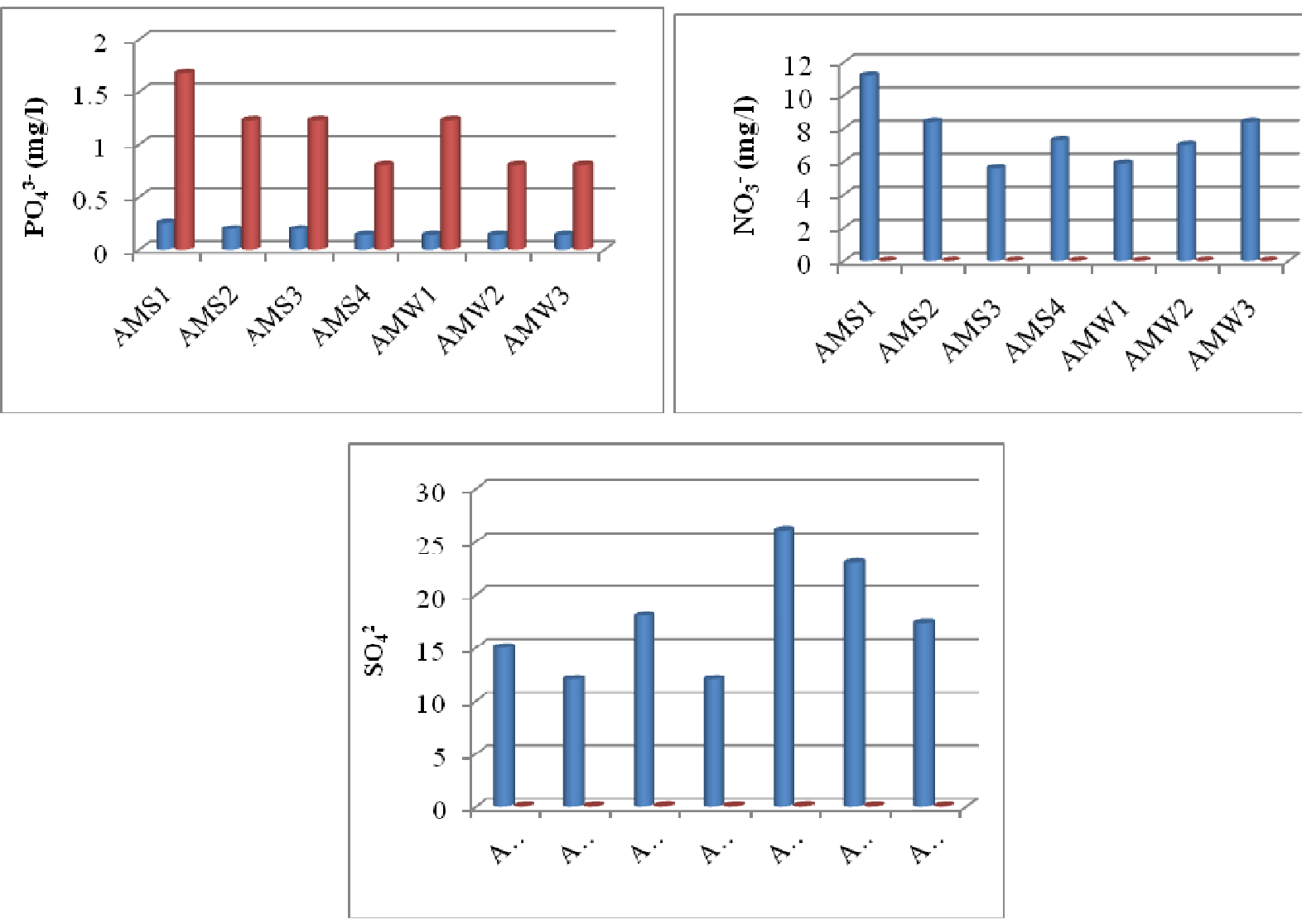

Figure 4. Seasonal variation of anions $\left(\mathrm{Cl}^{-}, \mathrm{HCO}_{3}{ }^{-}, \mathrm{PO}_{4}{ }^{3-}, \mathrm{NO}_{3}{ }^{-}, \mathrm{SO}_{4}{ }^{-}\right.$).

\subsubsection{Hydrochemical Facies}

The piper diagram provides information on the different chemical facies of the analysed water.

\section{Diagramme de Piper}

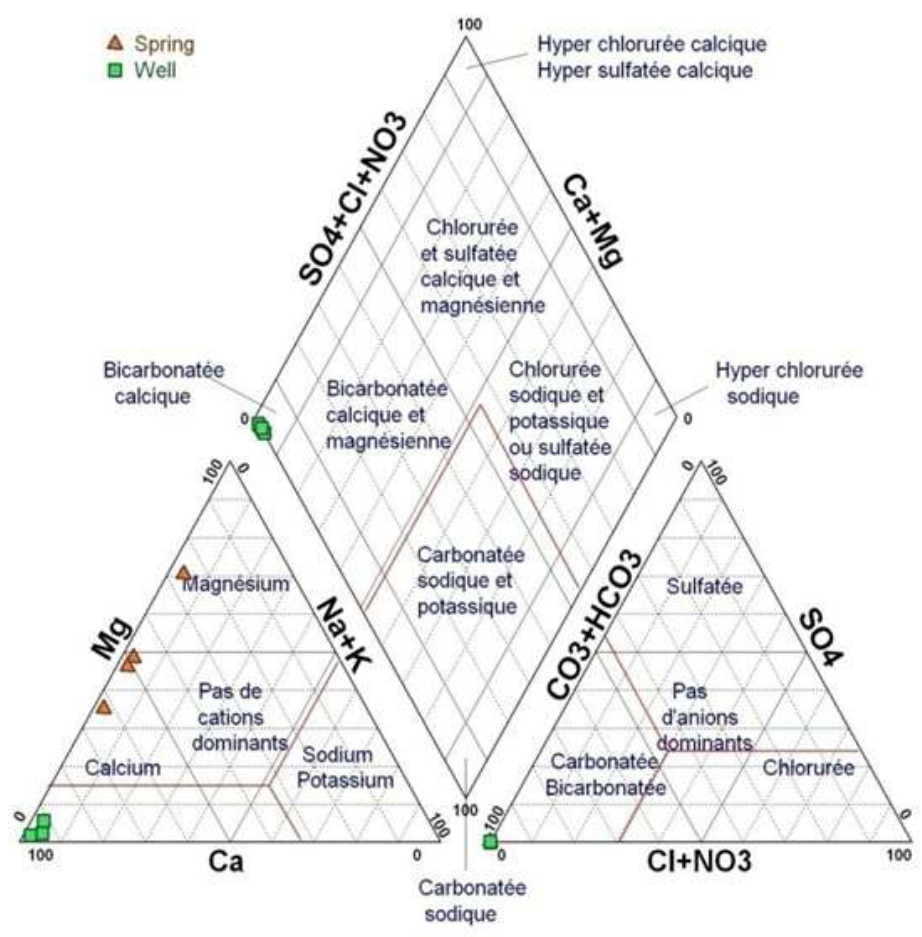




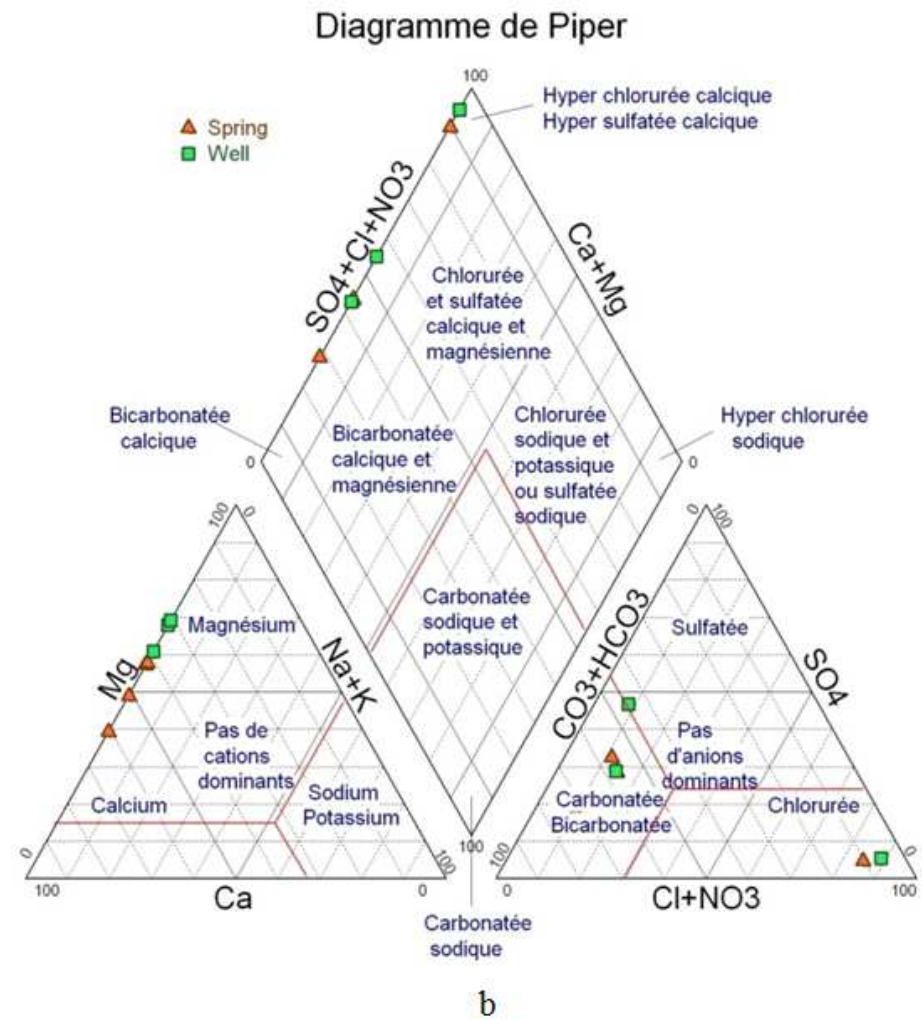

Figure 5. Piper's diagram [15], showing the water types in Bamenda III, a) dry season b) for rainy season.

In the dry season, the major cations and anions presented one facies of the Ca- Mg-HCO3 type (Figure 5a) whereas in the rainy season the major cations and anions presented two facies of $\mathrm{Ca}-\mathrm{Mg}-\mathrm{HCO} 3$ type and $\mathrm{Ca}-\mathrm{Mg}-\mathrm{SO} 4$ type (Figure $5 b)$. This significant difference may be due to the hydrochemical processes taking place within the aquifer systems in different seasons. The mineralization process is more homogeneous in the dry season while in the rainy season mineralization is heterogeneous and influenced by the weathering of rocks.

\subsection{Bacteriological Characteristics}

Three (03) water points (AMS1, AMS2 and AMW2) were analysed for bacteria indicators of pollution as well as for specific microbes (Table 4).

Table 4. Bacterial counts of specific microbes isolated in springs and well in the rainy and dry seasons.

\begin{tabular}{|c|c|c|c|c|c|c|c|c|c|c|}
\hline & \multicolumn{2}{|c|}{$\begin{array}{l}\text { Enterobacteria } \\
(\mathbf{c f u} / \mathbf{1 0 0 m l})\end{array}$} & \multicolumn{2}{|c|}{$\begin{array}{l}\text { E. coli } \\
\text { (cfu/100ml) }\end{array}$} & \multicolumn{2}{|c|}{$\begin{array}{l}\text { Streptococcus } \\
\text { (cfu/100ml) }\end{array}$} & \multicolumn{2}{|c|}{$\begin{array}{l}\text { Salmonella } \\
\text { (cfu/100ml) }\end{array}$} & \multicolumn{2}{|c|}{$\begin{array}{l}\text { Proteus } \\
(\mathrm{cfu} / \mathbf{1 0 0 m l})\end{array}$} \\
\hline & $\begin{array}{l}\text { Rainy } \\
\text { Season }\end{array}$ & $\begin{array}{l}\text { Dry } \\
\text { Season }\end{array}$ & $\begin{array}{l}\text { Rainy } \\
\text { Season }\end{array}$ & $\begin{array}{l}\text { Dry } \\
\text { Season }\end{array}$ & $\begin{array}{l}\text { Rainy } \\
\text { Season }\end{array}$ & $\begin{array}{l}\text { Dry } \\
\text { Season }\end{array}$ & $\begin{array}{l}\text { Rainy } \\
\text { Season }\end{array}$ & $\begin{array}{l}\text { Dry } \\
\text { Season }\end{array}$ & $\begin{array}{l}\text { Rainy } \\
\text { Season }\end{array}$ & $\begin{array}{l}\text { Dry } \\
\text { Season }\end{array}$ \\
\hline $\mathrm{AMS}_{1}$ & 50 & 100 & 20 & 30 & 200 & 50 & 00 & 00 & 00 & 10 \\
\hline $\mathrm{AMS}_{2}$ & 20 & 200 & 10 & 20 & 100 & 70 & 00 & 10 & 00 & 50 \\
\hline $\mathrm{AMW}_{2}$ & 200 & 300 & 100 & 200 & 300 & 200 & 60 & 15 & 10 & 00 \\
\hline Average & 90 & 200 & 43,33 & 83,33 & 200 & 106,67 & 20 & 8,33 & 3,33 & 20 \\
\hline
\end{tabular}
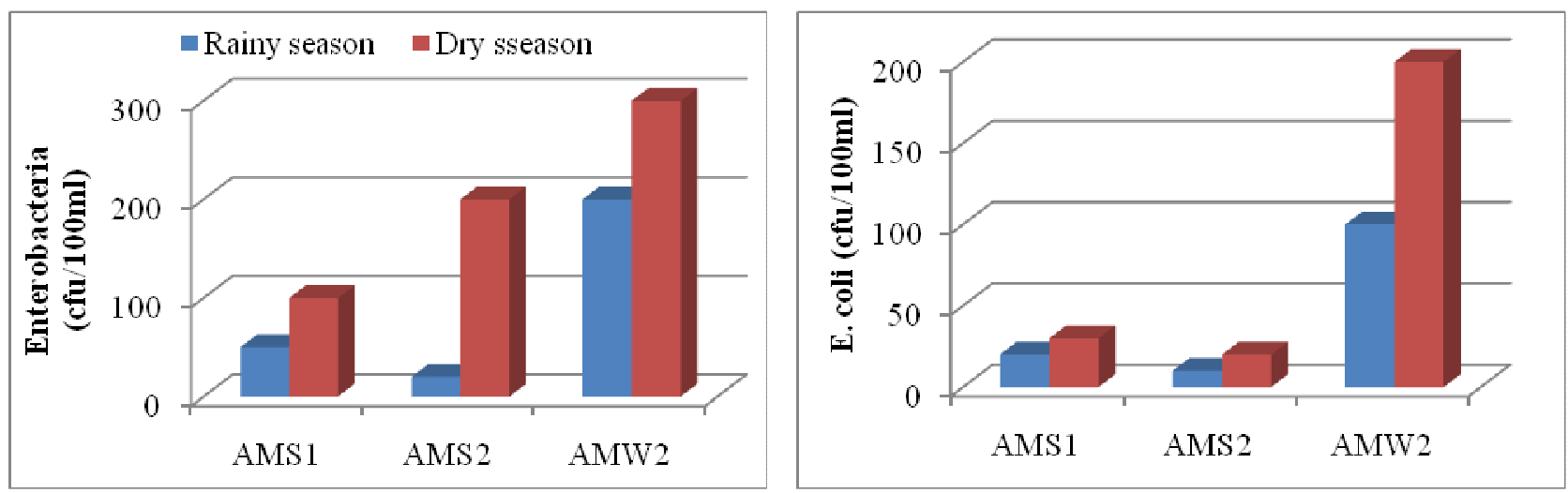

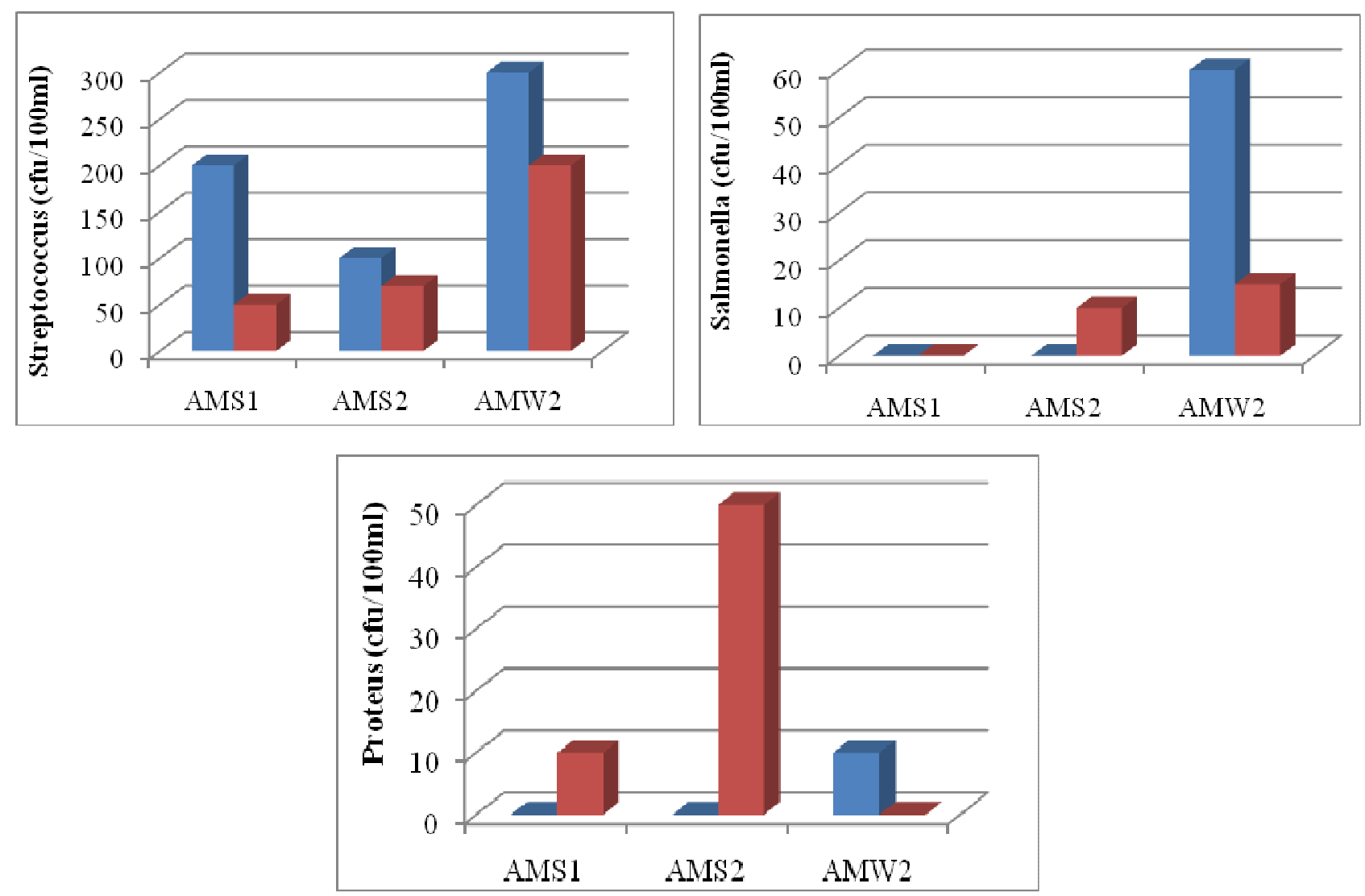

Figure 6. Seasonal variation of bacteria indicators of pollution and specific microbes.

Enterobacteria, Escherichia coli, Streptococcus, Salmonella and Proteus were detected in the water samples and the species richness varied from one water point to another: Enterobacteria, Escherichia coli and Streptococcus were present in all the sampling points whereas Salmonella and Proteus were present only in some sampling points. Higher counts were recorded in the dry season than in the rainy season with Streptococcus presenting an exception with higher counts in the rainy season $(100$ to $300 \mathrm{cfu} / 100 \mathrm{ml})$ than in the dry season (50 to $200 \mathrm{cfu} / 100 \mathrm{ml}$ ). Enterobacteria levels were particularly high during the rainy season (20 to 200 $\mathrm{cfu} / 100 \mathrm{ml})$ but increased greatly during the dry season $(100$ to $300 \mathrm{cfu} / 100 \mathrm{ml})$. On the other hand Salmonella and Proteus were absent in springs (AMS1 and AMS2) in the rainy season but registered an increase in the dry season.

\section{Discussion}

The major ions chemistry of groundwater and compositional relations among ionic species can reveal the origin of solutes and processes that generate water composition [16-18].

The acidic to barely acidic water may be an indication that the dissolve carbonates were predorminantly in the form of $\mathrm{HCO}_{3}$; In Ghana [19] and in Nigeria [20] low $\mathrm{pH}$ has also been reported from granitic basement complex aquifers and were related to the same processes.

\subsection{Cations}

The relative abundance of the cations was as follows $\mathrm{Ca}^{2+}>\mathrm{Mg}^{2+}>\mathrm{K}^{+}>\mathrm{Na}^{+}$, this shows that

$\mathrm{Ca}^{2+}$ is the most abundant cation followed by $\mathrm{Mg}^{2+}$ in the springs and wells of the study area. Their main source may be from the weathering of calco-sodico feldspaths and hornblende in the basic rock. [21] explains that these minerals are found in basic rocks.

2 Hornblende $+30 \mathrm{H}^{+}+9 \mathrm{H}_{2} \mathrm{O} \rightarrow$ Kaolinite $+12 \mathrm{H}_{4} \mathrm{SiO}_{4}+$ $4 \mathrm{Ca}^{2+}+10 \mathrm{Mg}^{2+}+2 \mathrm{Na}^{+}$.

The most common source of $\mathrm{K}^{+}$is the silicate minerals: orthoclase, nepheline, leucite and biotite [22]. The basement rock of the study area is composed of granite and the $\mathrm{K}^{+}$is probably from the dissolution of orthoclase (KAlSi3O8)) and $\mathrm{Fe} \mathrm{Mg}$ minerals like biotite $\left(\mathrm{K}(\mathrm{Mg} \mathrm{Fe})_{3}\left(\mathrm{AlSi}_{3}\right) \mathrm{O}_{10}(\mathrm{OH}, \mathrm{Fe})_{2}\right.$ present in the granites.

2 Orthoclase $+2 \mathrm{H}^{+}+9 \mathrm{H}_{2} \mathrm{O} \rightarrow$ Kaolinite $+4 \mathrm{H}_{4} \mathrm{SiO}_{4}+2 \mathrm{~K}^{+}$

2 Biotite $+13 \mathrm{H}^{+}+\mathrm{CO}_{2}+2 \mathrm{H}_{2} \mathrm{O} \rightarrow$ Kaolinite $+4 \mathrm{H}_{4} \mathrm{SiO}_{4}+$ $6 \mathrm{Fe}^{2+}+6 \mathrm{Fe}^{3+}+\mathrm{HCO}_{3}^{-}+2 \mathrm{~K}^{+}$

Albite in the granites is the probable source of the $\mathrm{Na}^{+}$

2 Albite $+2 \mathrm{H}+9 \mathrm{H}_{2} \mathrm{O} \rightarrow$ kaolinite $+4 \mathrm{H}_{4} \mathrm{SiO}_{4}+2 \mathrm{Na}^{+}$

Meanwhile the main source of $\mathrm{NH}_{4}^{+}$is probably from fertilizers used in farms which is being leached into the water while natural sources such as organic (metabolic processes) and inorganic (rock weathering and hydrothermal activity) could also contribute to the presence of $\mathrm{NH}_{4}^{+}$.

The source of $\mathrm{Fe}^{2+}$ is from the hydrolysis of $\mathrm{Fe} \mathrm{Mg}$ rich minerals such as biotite in the granite and diorite of the study 
area. The low concentration of $\mathrm{Fe}^{2+}$ is due to its being retained in the soil for the formation of clays, oxides and hydroxides during weathering $[23,24]$.

\subsection{Anions}

The relative abundances of anions $(\mathrm{mg} / \mathrm{l})$ in different samples were as follows: $\mathrm{HCO}_{3}{ }^{-}>\mathrm{SO}_{4}{ }^{-}>\mathrm{NO}_{3}{ }^{-}>\mathrm{PO}_{4}{ }^{3^{-}}>\mathrm{Cl}^{-}$.

$\mathrm{HCO}_{3}{ }^{-}$concentrations were high with average values ranging from $16.78-174.18 \mathrm{mg} / \mathrm{l}$. All the samples had values below the WHO value $(200 \mathrm{mg} / \mathrm{l})$. The dorminance of $\mathrm{HCO}_{3}{ }^{-}$ is consistent with most natural waters along the CVL [25]. The primary source is the dissolved $\mathrm{CO}_{2}$ in rain water and the decay of organic matter at the surface which may release $\mathrm{CO}_{2}$ for dissolution [22]. Weathering, precipitation and organic decay probably account for the dominance of this ion, $\mathrm{CO}_{2}+$ $\mathrm{H}_{2} \mathrm{O} \rightarrow \mathrm{H}^{+}+\mathrm{HCO}_{3}^{-}$or $\mathrm{CO}_{2}+\mathrm{H}_{2} \mathrm{O}+\mathrm{CO}_{2} \rightarrow 2 \mathrm{HCO}_{3}^{-}$.

$\mathrm{SO}_{4}{ }^{2-}$ could derive from natural source such as sulphate minerals common in igneous rocks [22]. It can also be from the oxidation of pyrite; $\mathrm{Fe} \mathrm{S}_{2}+2 \mathrm{O}_{2}+\mathrm{H}_{2} \mathrm{O} \rightarrow 2 \mathrm{SO}_{4}{ }^{2-}+\mathrm{H}_{2}$. The low concentrations may be a consequence of gradual dissolution [26].

The presence of $\mathrm{PO}_{4}{ }^{3^{-}}$probably indicates leaching of phosphate fertilizers from nearby farmlands.

Low concentrations of $\mathrm{NO}_{3}{ }^{-}$in the dry season suggest their adsorption in organic colloids [27]. The potential source may also be shallow pit toilets and oxidation of organic matters in biochemical processes as well as the oxidation of ammonia by Nitrosomonas and Nitrobacter bacteria.

$\mathrm{Cl}^{-}$was absent in the rainy season and according to [28], at high altitude the decrease in $\mathrm{Cl}^{-}$concentration is due to smaller rainfall inputs caused by rapid decrease of the absolute humidity and temperature with elevation resulting in a smaller condensation. An anormalous $\mathrm{Cl}^{-}$concentration of $158 \mathrm{mg} / \mathrm{l}$ and $270 \mathrm{mg} / \mathrm{l}$ were obtained in the rainy season which might have been due to disinfection through chlorination.

\section{Groundwater Suitability for Drinking and Domestic use in Bamenda III}

The analytical results were evaluated to ascertain the suitability of groundwater in the study area for drinking and domestic purposes based on the WHO, 2004 standard (Table 5 ) and the $[28,29]$ classification (Table 6).

Table 5. Groundwater quality in Bamenda III in compliance with WHO (2004) drinking water standard.

\begin{tabular}{lll}
\hline Parameter & Range in study area & WHO limit (2004) \\
\hline $\mathrm{pH}$ & $4.1-6.5^{*}$ & $6.5-8.5$ \\
$\mathrm{~T}\left(\mathrm{C}^{\circ}\right)$ & $20.7-25.9^{*}$ & 15 \\
$\mathrm{EC}(\mathrm{ys} / \mathrm{cm})$ & $0.04-2.38$ & 750 \\
$\mathrm{Ca} 2+(\mathrm{mg} / \mathrm{l})$ & $110-1770^{*}$ & 75 \\
$\mathrm{Mg} 2+(\mathrm{mg} / \mathrm{l})$ & $97.05-236.85^{*}$ & 30 \\
$\mathrm{Na}+(\mathrm{mg} / \mathrm{l})$ & $4.02-13.52$ & 200 \\
$\mathrm{~K}+(\mathrm{mg} / \mathrm{l})$ & $12.02-12.97$ & 100 \\
$\mathrm{Cl}-(\mathrm{mg} / \mathrm{l})$ & $0-270^{*}$ & 250 \\
$\mathrm{NO} 3^{-}(\mathrm{mg} / \mathrm{l})$ & $2.801-5.601$ & 10 \\
$\mathrm{SO} 42^{-}(\mathrm{mg} / \mathrm{l})$ & $6.025-11.525$ & 250 \\
$\mathrm{HCO} 3-(\mathrm{mg} / \mathrm{l})$ & $16.78-174.18$ & 200 \\
\hline
\end{tabular}

* values above WHO limit
EC, $\mathrm{Na}^{+}, \mathrm{K}^{+}, \mathrm{NO}_{3}{ }^{-}, \mathrm{SO}_{4}{ }^{2-}$, and $\mathrm{HCO}_{3}{ }^{-}$concentrations of the analysed water were under the limits required by the WHO (2004) drinking water norms whereas $\mathrm{pH}$ and $\mathrm{T}\left(\mathrm{C}^{\circ}\right)$ values, $\mathrm{Ca}^{+}, \mathrm{Mg}^{+}$, and $\mathrm{Cl}^{-}$concentration values were above the WHO limits.

$\mathrm{pH}$ values for the study area ranged from 4.1 to 6.5 and were below the WHO guideline limit (Table 6). Even though $\mathrm{pH}$ has no effect on human health, it is closely related to other chemical constituents of water [3].

The temperature values were high which favour bacterial growth and may increase taste, odour, colour and corrosion problems.

$\mathrm{Ca}^{+}$and $\mathrm{Mg}^{+}$values were much higher than the WHO norms. The presence of these alkaline earth metals determines water hardness. [30] expresses Hardness of water as Total Hardness $(\mathrm{TH})$ and is given by $\mathrm{TH}=2.5 \mathrm{Ca}+4.1 \mathrm{Mg}$. Though hardness has no adverse effect on human health, there is an esthetic concern because of the unpleasant taste that it impacts. It can prevent formation of lather with soap, increase the boiling point of water and may cause encrustation in water supply distribution system. According to [31], there is some suggestive evidence that long term comsumption of extremely hard water might lead to increase urolithiasis, ancephaly, parental mortality and some kind of cancer and cardiovascular disorders. On the other hand water softness (low in $\mathrm{Ca}^{2+}$ and $\mathrm{Mg}^{2+}$ ) could be a health problem since soft water has been linked to cardiovascular ailments [32].

WHO limit for $\mathrm{Cl}^{-}$is $250 \mathrm{mg} / \mathrm{l}$ and sample $\mathrm{AMW}_{2}$ exceed this limit in the rainy season. Higher concentration may cause gastrointestinal irritation when associated with $\mathrm{Na}^{+}$and $\mathrm{Mg}^{2+}$ [33].

According to the [29] classification of drinking water, two of the sampling points $\left(\mathrm{AMS}_{1}\right.$ and $\left.\mathrm{AMW}_{2}\right)$ could be placed in category $\mathrm{C}$ and one $\left(\mathrm{AMS}_{2}\right)$ under category $\mathrm{B}$ in the rainy season (Table 5). In the dry season, $\mathrm{AMS}_{1}$ and $\mathrm{AMS}_{2}$ fell under category $\mathrm{C}$ and $\mathrm{AMW}_{2}$ under category $\mathrm{D}$ (Table 5).

Table 6. Category of water samples according to Cheesbrough classification of drinking water.

\begin{tabular}{llll}
\hline Sampling points & Seasons & Mean count & Category \\
\hline \multirow{2}{*}{$\mathrm{AMS}_{1}$} & Rainy & 30 & $\mathrm{C}$ \\
& Dry & 35 & $\mathrm{C}$ \\
$\mathrm{AMS}_{2}$ & Rainy & 10 & $\mathrm{~B}$ \\
& Dry & 30 & $\mathrm{C}$ \\
$\mathrm{AMW}_{2}$ & Rainy & 40 & $\mathrm{C}$ \\
& Dry & 90 & $\mathrm{D}$ \\
\hline
\end{tabular}

These bacterial loads indicate an excessive level of pollution of the water samples [01]. Feacal coliforms such as E. coli are prevalent in the digestive tracts of warm - blooded animals and their presence in water is definite evidence of feacal contamination.

Contaminations of water points are much higher in the dry season than in the rainy season. This may be feacal bacteria accumulate and settle as a result of greater contact between water and sediments which enables significant sedimentwater exchange [34]. 


\section{Conclusion}

Bamenda III, which is petrographicaly made up of two units, plutonic (granite) and volcanic (Rhyolite, basalt and trachyte), was subjected to physico-chemical and bacteriological analyses of its 7 water points: 03 wells and 04 springs.

All water samples had $\mathrm{pH}$ range between 4.1 and 6.5 which is below the WHO standard for drinking water. The low EC and TDS classified the water as low-mineralised and freshwater. The relative abundance of major cations and anions in the water $(\mathrm{mg} / / \mathrm{l})$ was $\mathrm{Ca}^{2+}>\mathrm{Mg}^{2+}>\mathrm{K}^{+}>\mathrm{Na}^{+}$and $\mathrm{HCO}_{3}{ }^{-}>\mathrm{SO}_{4}{ }^{2-}>\mathrm{NO}_{3}{ }^{-}>\mathrm{PO}_{4}{ }^{3-}$ respectively. Major ion concentrations were low, and below maximum values of the WHO standards for drinking water, except for $\mathrm{Ca}^{2+}$ and $\mathrm{Mg}^{2+}$ which were higher classifying the water as hardwater.

The variety and level of faecal bacteria recorded indicate that this area is under anthropogenic influence and receives feacal contamination. None of the water points are suitable for drinking. For this reason, the population of Bamenda III, $80 \%$ of which depends on the well and spring water for drinking and domestic purposes, may face serious health problems if appropriate actions are not taken to prevent and mitigate the problems.

\section{References}

[1] Katte V.Y., Fonteh M.F., Guemuh G.N. (2003): Domestic water quality in urban centres in Cameroon: A case study of Dschang in the West Province. Afr. Water. J. Pilot ed.: 43-54.

[2] Molua E.L., Lambi C.M. (2006) : Climate hydrology and water resources in Cameroon. CEEPA.

[3] Ako A.A. (2011): Hydrogeological study on groundwater in the Banana Plain and Mount Cameroon area - Cameroon Volcanic Line. Kumamoto University.

[4] Auippa A., Bellomoa S., Bruscab L., Alessandrolo W., Federico C. (2003): Natural and Anthropogenic factors affecting ground water quality of an Active volcano (Mt. Etna, Italy): Applied Geochemistry 18: 863-882.

[5] Mafany G.T., Fantong W.Y., Nkeng G.E. (2006): groundwater quality in Cameroon and its vulnerability to pollution. In Groundwater pollution in Africa. Edited by Yongxin $\mathrm{Xu}$ and Brent Usher. Taylor and Francis London

[6] Ako A.A., Shimada J., Hosono T., Kagabu M., Akoachere R.A., Nkeng G.E., Eneke G.T., Fouepe Appelo C., Postma D. (2005): Geochemistry, groundwater, and pollution (2nd ed.). Balkema, Amsterdam p. 635.

[7] Edmunds W.M., Smedley P.L. (1996): Groundwater geochemistry and health: An overview. In: Appleton JD, Fuge R, McCall GJH (eds.) Environmental geochemistry and health with special reference to developing countries. Geological Society Special Publication No.113, pp. 91-105.

[8] Deutsch W.J. (1997): Groundwater geochemistry: Fundamentals and applications to contamination. CRC Press, Florida p. 221
[9] Ramesh K., Elango L. (2012) : Groundwater quality and its suitability for domestic and agricultural use in Tondiar river basin, Tamil Nadu, India. Environ. Monit. Assess. 184:38873899.

[10] Entry J.A., Farmer N. (2001): Movement of coliform bacteria and nutrients in groundwater flowing through basalt and sand aquifers. J. Environ. Q. 30: 1533 - 1539.

[11] Acho C. (1998): Human interface and environmental instability: Addressing the environmental problems of rapid urban growth. In: Environment and urbanisation. Vol. 10. No. 2. London. P.415.

[12] Nzenti J.P., Abaga B., Suh E.C., Nzolang C., (2010): Petrogenesis of peraluminous magmas from the AkumBamenda massifs, Pan-African Fold Belt.International Geology Review. 1-29p.

[13] Njilah I.K., (1991): Geochemistry and petrogenesis of the Tertiary-Quaternary volcanic rocks from Oku Ndu area, North West Cameroon. PhD Thesis, Leeds University, 350pp+1map.

[14] Kamgang P., Njonfang E., Nono A., Gountie D.M., Tchoua F. ( 2010):Petrogenesis of a silicic magma system: geochemical evidence from Bamenda Mountains, NW Cameroon, Cameroon Volcanic Line; Journal of African Earth Sciences 58: $285-304$

[15] Piper A.M. (1944): A graphic procedure in the geochemical interpretation of water analyses. Transactions American Geophysicists Un. Papers, Hydrology, 914-929.

[16] Hounslow A.W. (1995): Water quality data: Analysis and interpretation. Lewis Publishers, Boca Raton.

[17] Demlie M., Wohnlich S., Wisotzky F., Gizaw B. (2007) : Groundwater recharge, flow and hydrogeochemical evolution in a complex volcanic aquifer system, central Ethiopia. Hydrogeol. J. 15: 1169-1181.

[18] Tay C.K. (2012) : Hydrochemistry of groundwater in the Savelugu-Nanton District, Northern Ghana. Environ. Earth Sci. 67: 2077-2087.

[19] Adomako D., Osae S., Akiti T.T., Faye S., Maloszewski P. (2011): Geochemical and isotopic studies of groundwater conditions in the Densu River Basin of Ghana. Environ. Earth Sci. 62:1071-1084.

[20] Edet A., Nganje T.N., Ukpong A.L., Ekwere A.S. (2011) : Groundwater chemistry and quality of Nigeria: A status review. Afr. J. Environ. Sci Technol. 5 (13): 1152-1169.

[21] Marzoli A., Piccirillo E.M., Renne P.R., Bellien G., Facumin G.M., Nyobe J., Tongwa A.T. (2000): The CVL Revisited: petrogenesis of continental Basaltic mangmas form lithospheric and Asthenospheric Mantle sources; Journal of petrology; 41(1): 87-109.

[22] Karanth K.R. (1987): Groundwater Assessment: Development and management; Tatamc Grawl Hill publishing company limited; 7 west patel Nagar, New Delhi; 488pp.

[23] Goldschmidt (1954): Geochemistry. A Muir (éd) clarendo press, Oxford 730p

[24] Millot G. (1964): Geologie des argiles Masson et Cie (ed) Paris , $499 \mathrm{p}$

[25] Tanyileke G. Z., Kusakabe M., Evans W. C., (1996): Chemical and isotopic characteristics of fluids along the CVL, Cameroon - Journal of African Earth Sciences, 22. (4): 433-441. 
[26] Ngwa M. (2013): Hydrochemical variation of groundwater in Bafut Subdivision (North West Region, Cameroon).

[27] Fonge B.A., Egbe E.A., Fongod A.N., Tening A.S., Achu R.M., Yinda G.S., Mvondo Z. (2012): Effects of land use on macrophyte communities and water quality in the Ndop wetland plain, Cameroon. J. Agric. Soc. Sci. 12: 41-49.

[28] Benedetti M.F., Dia A., Riotte J., Chabaux F., Gerald M. Boulegue J., Fritz B., Chauvel C., Bulourde M., Deruelle B., IIdefonse P. (2003): Chemical weathering of basaltic lava flows undergoing extreme climatic conditions: the water geochemistry record. Chemical geology 2011- 17.

[29] Cheesbrough M. (1991). Medical Laboratory manual for tropical countries. Low priced edition, Daddington, Cambridgshire.

[30] Todd D. k. (1980): Goundwater Hydrogeology. New York : Wiley.
[31] Durvey V.S., Sharma L.L., Saini V.P., Shama B.K. (1991): Handbook on the methodology of water quality assessment in India: Rajasthan Agriculture University.

[32] Kozisek F. (2005): Health risks from drinking demineralised water. In: Nutrients in drinking water. World Health Organization, Geneva. pp. 148-163.

[33] Garg V.K., Suthar S., Singh S., Sheoran A., Garima M., Jain S. (2009): Drinking water quality of Southwestern Hanyana India : Assessing human health risks associated with hydrochemistry. Environmental Geology. Dio: 10. 1007/s00254-008 1636-y.

[34] Mitsch W.J., Gosselink J.G. (2000): Wetlands. 920 p. wiley, New York, USA. 